\title{
Study on the Frequency of Heavy Rainfall in Huong Khe District, Ha Tinh Province
}

\author{
Nguyen Van Loi ${ }^{1}$, Le Quang Dao, ${ }^{2, *}$ Dong Thu Van², Pham Lan Hoa ${ }^{2}$, Le Thanh Tung ${ }^{2}$ \\ ${ }^{1}$ Center for Water Resources Consultant and Technology Transfer-MARD \\ ${ }^{2}$ Institute for Geological Sciences-Vietnam Academy of Science and Technology
}

Received 15 March 2017

Revised 15 April 2017; Accepted 28 June 2017

\begin{abstract}
Rainfall intensity, duration and frequency of 24 consecutive hours or longer (48h, 72h, 96h) are very essential for the assessment of flood risk and the design of the reservoirs and dams in Huong Khe district, Ha Tinh province. The analysis of flood-causing rainfall and the actual floods from 1990 to 2012 has shown that floods usually occur when: a) 24-hour continuous rainfall reacheds $710.6 \mathrm{~mm}$ or more; b) Heavy rains which lasted longer than 24 hours and reached $548.9 \mathrm{~mm} / 24 \mathrm{~h}$ to $630.2 \mathrm{~mm} / 48 \mathrm{~h}$ or more; c) Heavy rains lasted from 72 hours to 96 hours and reached from $534.5 \mathrm{~mm} / 72 \mathrm{~h}$ to $575.6 \mathrm{~mm} / 96 \mathrm{~h}$. The following conclusions have been drawn from analysis results of development of the empirical and theoretical exceedance frequencies of Pearson III distribution of 24h-96h heavy rainfall: a) All the theoretical and empirical frequency data have very high correlation coefficient from 0.891 ( $24 \mathrm{~h}$ rainfall) to about 0.948 ( $72 \mathrm{~h}-96 \mathrm{~h}$ rainfall); b) For $24 \mathrm{~h}$ rainfall, the actual rainfall of the empirical $P$ of $13 \%$ to $26 \%$ is about $40 \mathrm{~mm}$ lower than the theoretical rainfall, while the actual rainfall of the empirical $P$ of $8.7 \%$ is about $80 \mathrm{~mm}$ higher than the theoretical value, and that of the empirical $P$ of $4.35 \%$ is about $175 \mathrm{~mm}$ higher than the theoretical value; the actual rainfall at empirical $P$ of $8.7 \%$ is corresponding to theoretical $P$ of $4.5 \%$, and actual rainfall at empirical $P$ of $4.35 \%$ is corresponding to theoretical $P$ of $\sim 1 \%$; c) For $48 \mathrm{~h}$ and $72 \mathrm{~h}$ rainfall, the empirical and theoretical frequency data are very close to each other for the $P$ in the range of $8.7 \%$ to $30 \%$, only empirical $P$ of $4.35 \%$ is much far from theoretical one and corresponding to rainfall frequency of $\sim 1 \%$; d) For $96 \mathrm{~h}$ rainfall, the empirical and theoretical frequency data are very close to each other for most $P$ range, only empirical $P$ of $8.7 \%$ and $4.35 \%$ are somehow far from theoretical ones and corresponding to rainfall of theoretical frequencies of $\sim 4.5 \%$ and $\sim 1 \%$, respectively.
\end{abstract}

Keywords: Extreme, Frequency, Pearson, Gamma, Kritsky-Menken, Standard deviation, Coefficient of skewness.

\section{Introduction}

The natural disasters caused by extreme weather events, including floods due to heavy

\footnotetext{
${ }^{*}$ Corresponding author. Tel.: 84-902699994.

Email: ledaonew1@gmail.com

https://doi.org/10.25073/2588-1094/vnuees.4101
}

rain frequently occur in Central Vietnam, particularly in the North Central region. Two or three of weather patterns causing heavy rain such as tropical cyclones, inter tropical convergence zone (ITCZ), meridional convergence, cold surges, etc., which are active simultaneously or consecutively, combined with regional topography, bring about the 
typical flooding Central region (Nguyen Khanh Van, 2009 and 2012) [1, 2]. Huong Khe district is located in the Southwest of Ha Tinh province and surrounded with two major mountains: Tra Son Mountain in the East is a branch of Eastern Annamite Range extending to the ocean, the natural boundary with three districts Can Loc Thach Ha - Cam Xuyen; Giang Man Mountain in the West is a segment of the majestic Annamite Range, the border with Laos. Huong Khe district borders $\mathrm{Vu}$ Quang, Duc Tho districts in the North and Quang Binh province in the South. The topography of this district has two main types: the mountainous topography with the average elevation of 1,500 meters is complicatedly differentiated and strongly fragmented, forming different ecological zones; and the midland, hilly topography is the transition between high mountain and plain, along the Ho Chi Minh highway. With extreme weather patterns and fragmented hilly topography with severe slope, Huong Khe district often suffers from the heavy floods. Especially due to the impact of climate change, a lot of tropical cyclones, and devastating floods have continuously occurred in the Central region (Le Van Nghinh and Hoang Thanh Tung, 2006) [3].

One of the key parameters in assessment of flood magnitude, in design of reservoirs, in risk assessment of reservoir failure causing floods in the downstream area etc. is the rainfall frequency and magnitude in a certain period of time corresponding to that frequency. Vietnam Institute of Meteorology, Hydrology and Environment in 1999 [4] established a map of highest one-day rainfall for the Central region and Central Highlands with the frequency of $1 \%$ with data untill 1999. However, with the avaibility of more new observed data, especially in the context of the climate change, the results may not be valid for the present time. Morever, different values of frequency are required for different purposes of utilization. Also, different rainfall durations are required for different sizes of the area under flood accessment.
Le Van Nghinh (2004) [5] carried out the warning and prediction of beyond-design floods for medium and small reservoirs caused by heavy rainfalls. The study on selection of design flood criteria for designing emergency spillway carried out by Pham Ngoc Quy (2006) [6] indicated the importance of selection of beyond-design rainfall frequency. Such studies definitely require different values of frequency and corresponding rainfall magnitudes, which are possible expressed through frequency curves.

Nguyen Anh Tuan (2014) [7] determined the values of calculated daily rainfall according to the design frequency in 12 selected meteorological stations based on the data series of long actual rainfall from 1960 to 2010, in which the last time period was supposed to correspond to the new context of the impact of climate change, applied to calculate the design flow of small drainage works on the road in accordance with current design standard TCVN9845:2013 and determined the values of characteristic coefficient of the rain shape for the selected area in order to calculate the rainfall intensity corresponding to time of concentration of the basin and the design frequency used in the standard TCVN9845:2013. Ngo Le An (2016) [8] studied the details of change in the highest oneday rainfall (used to calculate design flood for medium and small basins) at some basins in the Central region and Central Highlands under the impact of climate change, according to the statistical method for error correction. Doan Thi Noi (2016) [9] carried out the study on temporal characteristics of flood, the analysis of development of rainfall frequency and intensity-duration-frequency curves for the Northern Vietnam in transportation design. The works' reults are most relevant to the transport design, and is directly related to the one-day maximal rainfall only.

Meanwhile, in many cases of study and design, rainfall intensity, duration and frequency (IDF), $24 \mathrm{~h}$ or more $(48 \mathrm{~h}, 72 \mathrm{~h}, 96 \mathrm{~h}$, etc.) continuous rainfall are really essential for 
the assessment of flood risk and the design of constructions, including reservoirs and dams. The paper aims to identify and develop the heavy rainfall frequencies in Huong Khe district, Ha Tinh province, which is located just in the South most of the Northern Vietnam central plain close to the Ngang mountainous pass, which is the natural topo-geographical boundary between Northern and Southern regions with distinguished heavy rainfalls (Nguyen Khanh Van, 2012) [2].

Huong Khe district is located in Ngan Sau River sub-basin, in Lam River basin (Dang
Dinh Kha et al., 2015) [10] and there is the meteorological observation station Huong Khe, level 2 (Figure 1) (but the rainfall measurement was hourly). In the East and Southeast of this station, there are two meteorological stations Ha Tinh and Ky Anh, observing the coastal area and coastal plains; in the Northwest, there is the meteorological station Huong Son, observing the meteorological characteristics of Ngan Pho River sub-basin. Therefore, in the article, the analysis of rainfall data in the meteorological station Huong Khe characterizes the Ngan Sau River sub-basin.

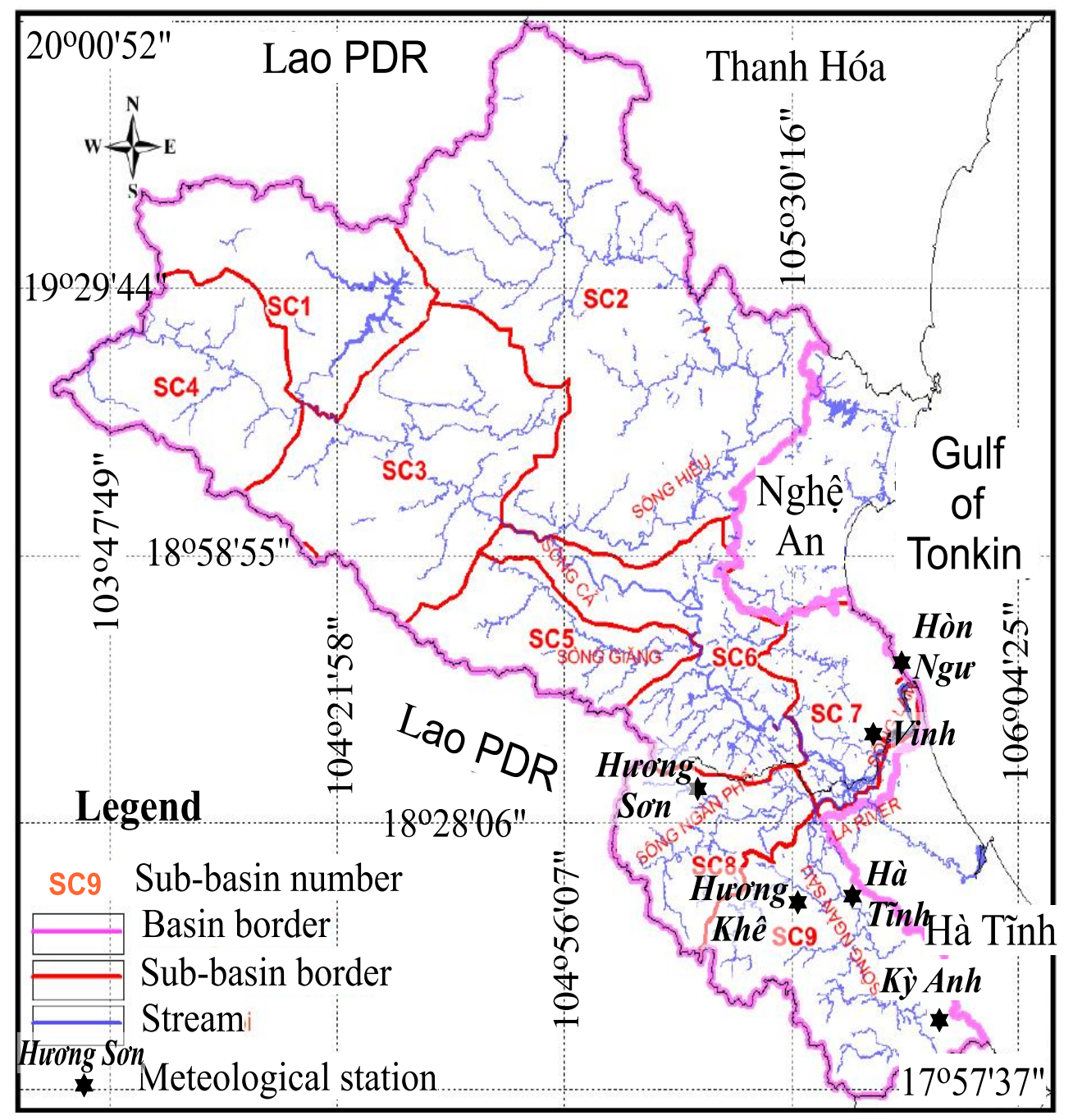

Figure 1. Boundaries between the sub-basins of Lam River basin [3]. 


\section{The weather patterns causing flood and the characteristics of flood in the region}

The weather patterns causing floods in Huong Khe - Ha Tinh are integral to those in the North Central region, including the following (Nguyen Khanh Van and Bui Minh Tang, 2004) [11]: tropical cyclones, inter tropical convergence zone (ITCZ), meridional convergence and cold surges. According to Nguyen Khanh Van and Bui Minh Tang (2004), in the past the flood-causing rainfalls in the region had been occured when there was a combination of three weather patterns - cool atmosphere, tropical convergence, with the following characteristics: 1) heavy rainfall duration is from 2 days to 8 days; 2) average duration of a single weather pattern is 2-3 days and the longest of 4 days; 3 ) average duration of the combination of weather patterns of 4-5 days. Accordingly, it is necessary to evaluate and determine the $48 \mathrm{~h}$ or longer rainfall.

Table 1. Floods in Nghe An - Ha Tinh, duration of rainfall and exceedance frequency P in Huong Khe

\begin{tabular}{|c|c|c|c|c|c|c|c|c|}
\hline \multirow{2}{*}{ No. } & \multirow{2}{*}{ Year } & \multirow{2}{*}{ From } & \multirow{2}{*}{ To } & \multirow{2}{*}{$\begin{array}{l}\text { Flood occurrence } \\
\text { after number of } \\
\text { days from heavy } \\
\text { rain start }\end{array}$} & $\begin{array}{l}\text { 24h rainfall } \\
(\mathrm{mm})\end{array}$ & $\begin{array}{l}48 \mathrm{~h} \text { rainfall } \\
(\mathrm{mm})\end{array}$ & $\begin{array}{l}72 \mathrm{~h} \text { rainfall } \\
(\mathrm{mm})\end{array}$ & $\begin{array}{l}\text { 96h rainfall } \\
(\mathrm{mm})\end{array}$ \\
\hline & & & & & $\mathrm{P}(\%)$ & $\mathrm{P}(\%)$ & $\mathrm{P}(\%)$ & $\mathrm{P}(\%)$ \\
\hline & 1995 & & & $\begin{array}{l}\text { Flooding not } \\
\text { occurred }\end{array}$ & 269.3 & 500.9 & 538.6 & 552.6 \\
\hline 1 & 1996 & $12 / 9$ & $15 / 9$ & 4 & $\begin{array}{l}376.6 \\
13.0\end{array}$ & $\begin{array}{l}585.6 \\
13.0\end{array}$ & $\begin{array}{l}598.4 \\
13.0\end{array}$ & $\begin{array}{l}698.7 \\
13.0\end{array}$ \\
\hline 2 & 2002 & $19 / 9$ & $22 / 9$ & 4 & $\begin{array}{l}304.7 \\
21.7\end{array}$ & $\begin{array}{l}464.7 \\
21.7\end{array}$ & $\begin{array}{l}534.5 \\
21.7\end{array}$ & $\begin{array}{l}575.6 \\
17.4\end{array}$ \\
\hline 3 & 2007 & $6 / 8$ & $8 / 8$ & 1 & $\begin{array}{l}710.6 \\
4.3\end{array}$ & $\begin{array}{l}946.2 \\
4.3\end{array}$ & $\begin{array}{l}1129.4 \\
4.3\end{array}$ & $\begin{array}{l}1144.4 \\
4.3\end{array}$ \\
\hline 4 & 2010 & $01 / 10$ & $5 / 10$ & 4 & $\begin{array}{l}313.4 \\
\sim 19\end{array}$ & $\begin{array}{l}454.5 \\
\sim 15\end{array}$ & $\begin{array}{l}461.8 \\
\sim 24\end{array}$ & $\begin{array}{l}604.8 \\
\sim 15\end{array}$ \\
\hline 5 & 2010 & $15 / 10$ & $17 / 10$ & 2 & $\begin{array}{l}548.9 \\
8.7\end{array}$ & $\begin{array}{l}630.2 \\
8.7\end{array}$ & $\begin{array}{l}727.5 \\
8.7\end{array}$ & $\begin{array}{l}912.2 \\
8.7\end{array}$ \\
\hline & 2012 & & & $\begin{array}{l}\text { Flooding not } \\
\text { occurred }\end{array}$ & 332.9 & 372.4 & 395.6 & 398.7 \\
\hline
\end{tabular}

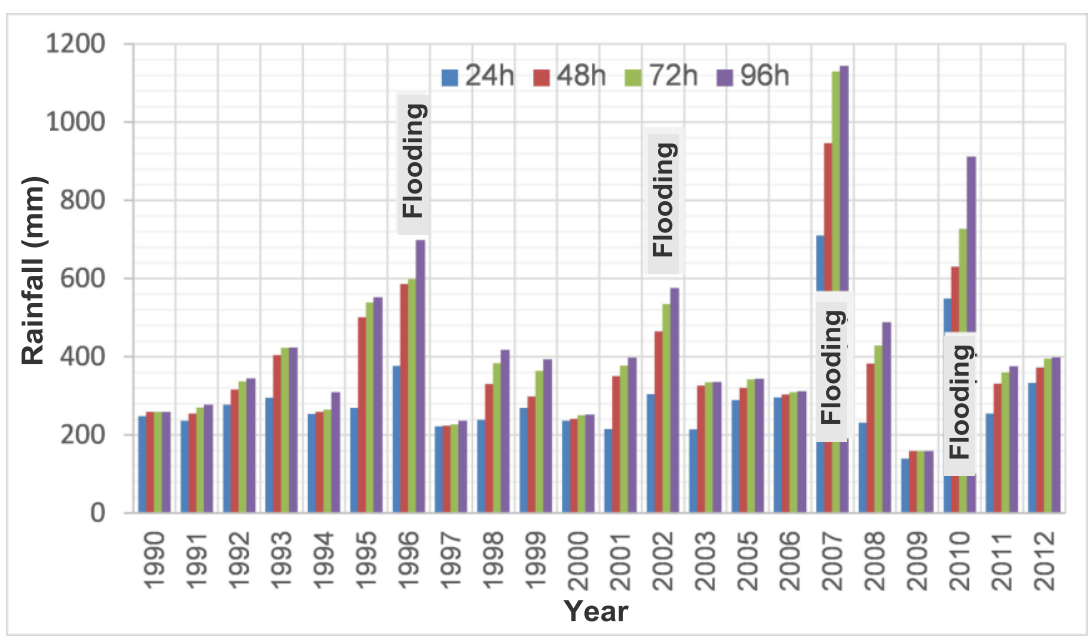

Figure 2. The highest continuous 24h-96h rainfall in Huong Khe district (1990-2012). 
Additionally, this paper's authors have carried out statistical analysis on the temporal rainfall characteristics of great floods in the North Central region from 1990 to 2012 and presented the characteristics of duration and flood-causing rainfall in the research area (Table 1 and Figure 2).

It is well-known that in each heavy rain, rainfall intensity changes temporally and spatially. Meanwhile flood occurrence is a combination of many natural factors of topography, geology, vegetation, etc. and characteristics of the heavy rain (Geoffrey S. Dendy, 1987) [12]. Therefore, the conclusions about the causes of flood only based on the rainfall distribution of heavy rain are not complete. However, in the framework of research with the basis that flood has the close relationship with rainfall distribution of the heavy rain, and natural conditions remain unchanged or play the minor role, according to the research results of rainfall distribution, it is possible to draw some following remarks about the relationship between duration and floodcausing rainfall in Huong Khe district, Ha Tinh:

Flood occurs when the continuous $24 \mathrm{~h}$ rainfall reaches $710.6 \mathrm{~mm} \mathrm{(2007)} \mathrm{(in} 2010$ despite the continuous $24 \mathrm{~h}$ rainfall of $548.9 \mathrm{~mm}$, flood did not occur);

Flood occurs when the heavy rain lasts over $24 \mathrm{~h}$ with the rainfall of over $548.9 \mathrm{~mm} / 24 \mathrm{~h}$ and $630.2 \mathrm{~mm} / 48 \mathrm{~h}$ (2010) (in 1995 the continuous $48 \mathrm{~h}$ rainfall was $500, .9 \mathrm{~mm} / 48 \mathrm{~h}$ but flood did not occur);

Flood occurs when the heavy rain lasts from $72 \mathrm{~h}$ to $96 \mathrm{~h}$ with the rainfall of over $534.5 \mathrm{~mm} / 72 \mathrm{~h}$ and $575.6 \mathrm{~mm} / 96 \mathrm{~h} \mathrm{(2002)} \mathrm{(in}$ 1995 the rainfall of $538.6 \mathrm{~mm} / 72 \mathrm{~h}$ to $552.6 \mathrm{~mm} / 96 \mathrm{~h}$ did not cause the flood).

Thus, it is possible to affirm that the development of frequency curve of continuous $24 \mathrm{~h}$ or longer rainfall has the practical significance in the assessment of flood risk in the region.

\section{The data and method in development of rainfall frequency curve in Huong Khe district, Ha Tinh province}

Data

Data used to build the maximum rainfall frequency of different durations are the hourly rainfall data measured at the meteorological station Huong Khe, in Huong Khe district, Ha Tinh province from 1990 to 2012 that are managed by National Meteorological Service, Ministry of Natural Resources and Environment [13]. This meteorological station belongs to the level 2 (the moderate detailed monitoring level), but the rainfall measurement belongs to level 1 (the most detailed monitoring level) since the measurment is every hour. The hourly rainfall data are used to calculate the maximal rainfall of continuous $24 \mathrm{~h}, 48 \mathrm{~h}, 72 \mathrm{~h}, 96 \mathrm{~h}$ to build the rainfall frequency curve.

\section{Empirical cumulative frequency}

Cumulative frequency $(P)$, also known as empirical exceedance frequency is the ratio between the number of occurrences of random variable values (rainfall) that are greater than or equal to the value of $x_{m}$ in a series of $\mathrm{n}$ effective data; the frequency $P$ is determined by the following formula (Ven Te Chow et al., 1988) [14]:

$$
P\left(X \geq x_{m}\right)=\frac{m-b}{n+1-2 b} 100 \%
$$

where $b$ is the parameter. When $b=0.5$, it corresponds to Hazen formula, $b=0.3$ Tregodayev formula, $b=0$ - Weibull formula, $b=3 / 8$ - Blom formula, $b=1 / 3$ - Turkey formula and $b=0.44-$ Gringorten formula.

In reality, when conducting the calculation for the annual maximum value in determining the number of iterative years $(T)$, U.S. Water Resources Council in 1981 used the value $b=0$, so $T=(n+1) / m$ and $P=m /(n+1)$. In this article, the authors use this formula in calculating the empirical frequency $P$. 
The extreme value distribution for maximum rainfall

Extreme value distribution for maximum rainfall, which belongs to any class of distribution according to Fisher and Tippet (1928) (Ven Te Chow et al., 1988), always converges to one of three types of extreme values (EV) I, II and III (EVI, EVII, EVIII) when the data series is long enough. The properties of extreme value type I, type II and type III were developed by Gumbel in 1941, by Frechet in 1927 and by Weibull in 1939, respectively (Ven Te Chow et al., 1988) [14]. In 1955 Jenkings (Ven Te Chow et al., 1988) [14] demonstrated that these three types of extreme value distribution are the specific cases of a general distribution with probability distribution function as follows:

$$
F(x)=\exp \left[\left(1-k \frac{x-u}{\alpha}\right)^{1 / k}\right]
$$

where $x$ is the extreme value; $k, u$ and $\alpha$ are the parameters.

When $k=0$ corresponding to type I (also known as Gumbel distribution); $k<0$ corresponding to type II (also known as Frechet distribution), then the lower limit of $x$ is $(u+$ $\alpha / k) \leq x \leq \infty$; and when $k>0$ corresponding to type III, then the upper limit of $x$ is $-\infty \leq x \leq(u+\alpha / k)$ (and in this case, the variable $-x$ is called the Weibull distribution).

In the study on rainfall distribution, the commonly used distributions are Pearson III and Kritsky-Menkel for type III and Gumbel for type I [15]. In this article, Pearson III and Krisky-Menkel distributions are used to determine the theoretical rainfall frequency in Huong Khe - Ha Tinh.

\section{Pearson III distribution}

Pearson III probability density function (also known as 3-parameter Gamma probability distribution) [14] of the random variable with value of $x$ has the following form:

$$
f(x)=\frac{\lambda^{\beta}(x-\varepsilon)^{\beta-1} e^{-\lambda(x-\varepsilon)}}{\Gamma(\beta)}
$$

where Gamma distribution $\Gamma(\beta)$ is defined as:

$$
\Gamma(\beta)=\int_{0}^{\infty} u^{\beta-1} e^{-u} d u
$$

with $x \geq \varepsilon$ (the lower limit of random variable); and three parameters of Gamma probability distribution are defined as follows:

$$
\lambda=\frac{s_{x}}{\sqrt{\beta}} ; \beta=\left(\frac{2}{C_{s}}\right)^{2} ; \varepsilon=\bar{x}-s_{x} \sqrt{\beta}
$$

where $\varepsilon$ is the lower limit of random variable (position parameter); $\lambda$ is the rate parameter; $\beta$ is the shape parameter; $\bar{x}$ is the average value; $s_{x}$ is the standard deviation; $C_{s}$ is the coefficient of skewness.

$$
\begin{aligned}
& \overline{\mathrm{x}}=\frac{1}{\mathrm{n}} \sum_{\mathrm{i}=1}^{\mathrm{n}} \mathrm{x}_{\mathrm{i}} ; \quad \mathrm{s}_{\mathrm{x}}=\sqrt{\frac{\sum_{\mathrm{i}=1}^{\mathrm{n}\left(\mathrm{x}_{\mathrm{i}}-\overline{\mathrm{x}}\right)^{2}}}{\mathrm{n}-1}} ; \\
& \mathrm{C}_{\mathrm{v}}=\frac{\mathrm{s}_{\mathrm{x}}}{\mathrm{x}} ; \quad \mathrm{C}_{\mathrm{s}}=\frac{\mathrm{n}}{(\mathrm{n}-1)(\mathrm{n}-2)} \sum_{\mathrm{i}=1}^{\mathrm{n}}\left(\frac{\mathrm{x}_{\mathrm{i}}-\overline{\mathrm{x}}}{\mathrm{s}_{\mathrm{x}}}\right)^{3}
\end{aligned}
$$

where $n$ is the number of samples, $C_{v}$ is the coefficient of variation.

When the variable that is greater than or equal to the value $x$ has the occurrence exceedance probability $P$, then $x$ is determined by the formula:

$$
x=\varepsilon+\operatorname{INV}(\Gamma(1-P, \beta, \lambda))
$$

and conversely, the occurrence exceedance probability $P$ of the variable that is greater than or equal to $x$ is determined by the formula:

$$
P(X \geq x)=\int_{x}^{\infty} f(x) d x
$$




\section{Kritsky-Menkel method}

The limitation of Pearson III distribution is when $C_{s}<2 C_{v}$, the random variable has negative value that does not fit the physical significance of meteorological phenomenon. Accordingly, Kritsky and Menkel established the revised probability distribution named Kritsky-Menkel method (Kritsky S. N. and Menkel M. F., 1967) [15], using Pearson III probability density function when $C_{s}=2 C_{v}$ as the basis. To calculate the values of $x$, Kritsky-Menkel built the lookup table of the value $K p$ depending on $C_{s}=m C_{v}, P$ and $C_{v}$. The value of random variable corresponding to the exceedance frequency $P$ is calculated according to the formula $x=\bar{x} K p$.

4. The frequency curve of maximum continuous $24 \mathrm{~h}, 48 \mathrm{~h}, 72 \mathrm{~h}, 96 \mathrm{~h}$ rainfall in Huong Khe district, Ha Tinh province

At the hydrometeorological station Huong Khe, in Huong Khe district, Ha Tinh province, the rainfall is observed hourly. The data on hourly rainfall observed at the meteorological station Huong Khe have been collected. The continuous $24 \mathrm{~h}, 48 \mathrm{~h}, 72 \mathrm{~h}, 96 \mathrm{~h}$ rainfall is calculated by using the moving total method of hourly skewness and then the maximum continuous $24 \mathrm{~h}, 48 \mathrm{~h}, 72 \mathrm{~h}, 96 \mathrm{~h}$ rainfall in the year is also determined. The rainfall frequency is determined by above empirical formula (1) (Ven Te Chow et al., 1988) [14] with the parameter value $b=0$. The methodology to calculate the parameters of Pearson III empirical and theoretical frequencies has been applied to each case of the maximum continuous $24 \mathrm{~h}, 48 \mathrm{~h}, 72 \mathrm{~h}, 96 \mathrm{~h}$ rainfall. The parameters of the frequency according to Pearson III distribution that has been calculated are average value $\bar{x}$, standard deviation $s_{x}$, coefficient of skewness $C_{s}$, coefficient of variation $C_{v}$, position parameter $\varepsilon$, shape parameter $\beta$, and rate parameter $\lambda$. The results of empirical frequency are shown in Table 2 that is the database to develop the Pearson III theoretical frequency.

By using Pearson III method and applying the statistical probability according to the formulas from (5) to (8), the Pearson III theoretical frequency and the parameters of distribution as well as statistical probability presented in Table 3 have been determined. The empirical and theoretical exceedance frequencies $P$ of Pearson III distribution of continuous $24 \mathrm{~h}-96 \mathrm{~h}$ rainfall are shown in Figures 3-6.

Table 2 . The maximum continuous $24 \mathrm{~h}-96 \mathrm{~h}$ rainfall and the exceedance probability

\begin{tabular}{lllllllll}
\hline Year & 24h & \multicolumn{3}{l}{$48 \mathrm{~h}$} & \multicolumn{3}{l}{$72 \mathrm{~h}$} & \multicolumn{3}{l}{$96 \mathrm{~h}$} \\
\cline { 2 - 9 } & $\begin{array}{l}\text { rainfall } \\
(\mathrm{mm})\end{array}$ & $P(\%)$ & $\begin{array}{l}\text { rainfall } \\
(\mathrm{mm})\end{array}$ & $P(\%)$ & $\begin{array}{l}\text { rainfall } \\
(\mathrm{mm})\end{array}$ & $P(\%)$ & $\begin{array}{l}\text { rainfall } \\
(\mathrm{mm})\end{array}$ & $P(\%)$ \\
\hline 1990 & 247.8 & 60.87 & 259.1 & 73.91 & 259.1 & 82.61 & 259.1 & 82.61 \\
1991 & 236.6 & 69.57 & 254.7 & 82.61 & 270.2 & 73.91 & 277.1 & 78.26 \\
1992 & 277.5 & 39.13 & 316.3 & 60.87 & 337.0 & 60.87 & 345.0 & 56.52 \\
1993 & 295.2 & 30.43 & 404.2 & 26.09 & 423.3 & 30.43 & 423.9 & 30.43 \\
1994 & 254.4 & 56.52 & 258.9 & 78.26 & 264.5 & 78.26 & 309.5 & 73.91 \\
1995 & 269.3 & 47.83 & 500.9 & 17.39 & 538.6 & 17.39 & 552.6 & 21.74 \\
1996 & 376.6 & 13.04 & 585.6 & 13.04 & 598.4 & 13.04 & 698.7 & 13.04 \\
1997 & 221.7 & 82.61 & 223.7 & 91.30 & 226.7 & 91.30 & 236.0 & 91.30 \\
1998 & 238.5 & 65.22 & 330.3 & 47.83 & 383.5 & 39.13 & 418.2 & 34.78 \\
\hline
\end{tabular}




\begin{tabular}{lllllllll}
\hline 1999 & 269.5 & 43.48 & 298.5 & 69.57 & 364.1 & 47.83 & 393.6 & 47.83 \\
2000 & 236.4 & 73.91 & 241.4 & 86.96 & 250.5 & 86.96 & 252.3 & 86.96 \\
2001 & 215.1 & 86.96 & 350.5 & 39.13 & 377.5 & 43.48 & 397.9 & 43.48 \\
2002 & 304.7 & 21.74 & 464.7 & 21.74 & 534.5 & 21.74 & 575.6 & 17.39 \\
2003 & 214.3 & 91.30 & 326.3 & 52.17 & 334.3 & 65.22 & 335.1 & 65.22 \\
2005 & 289.0 & 34.78 & 320.2 & 56.52 & 342.4 & 56.52 & 343.5 & 60.87 \\
2006 & 296.2 & 26.09 & 303.5 & 65.22 & 309.4 & 69.57 & 311.9 & 69.57 \\
2007 & 710.6 & 4.35 & 946.2 & 4.35 & 1129.4 & 4.35 & 1144.4 & 4.35 \\
2008 & 231.5 & 78.26 & 382.4 & 30.43 & 429.0 & 26.09 & 488.7 & 26.09 \\
2009 & 139.7 & 95.65 & 159.1 & 95.65 & 159.3 & 95.65 & 159.4 & 95.65 \\
2010 & 548.9 & 8.70 & 630.2 & 8.70 & 727.5 & 8.70 & 912.2 & 8.70 \\
2011 & 255.2 & 52.17 & 330.9 & 43.48 & 359.8 & 52.17 & 375.9 & 52.17 \\
2012 & 332.9 & 17.39 & 372.4 & 34.78 & 395.6 & 34.78 & 398.7 & 39.13 \\
\hline
\end{tabular}

Table 3. The parameters of statistical probability and Pearson III distribution

\begin{tabular}{|c|c|c|c|c|c|c|c|c|}
\hline \multirow{2}{*}{$\begin{array}{l}\text { Rainfall } \\
\text { duration }\end{array}$} & \multirow{2}{*}{$\begin{array}{l}\text { Average } \\
\text { value } \\
\frac{-}{x}\end{array}$} & \multirow{2}{*}{$\begin{array}{l}\text { Standard } \\
\text { deviation } \\
s_{x}\end{array}$} & \multirow{2}{*}{$\begin{array}{l}\text { Coefficient of } \\
\text { skewness } C_{s}\end{array}$} & \multirow{2}{*}{$\begin{array}{l}\text { Coefficient of } \\
\text { variation } C_{v}\end{array}$} & \multicolumn{3}{|c|}{ Parameters } & \multirow{2}{*}{$\begin{array}{l}\text { Correlation } \\
\text {-coefficient } R^{2}\end{array}$} \\
\hline & & & & & Position $c$ & $\begin{array}{l}\text { Shape } \\
\beta\end{array}$ & $\begin{array}{l}\text { Rate } \\
\lambda\end{array}$ & \\
\hline $24 \mathrm{~h}$ & 293.71 & 121.29 & 2.46 & 0.41 & 194.95 & 0.66 & 148.95 & 0.891 \\
\hline $48 \mathrm{~h}$ & 375.45 & 170.94 & 2.01 & 0.46 & 170.94 & 0.99 & 172.07 & 0.943 \\
\hline $72 \mathrm{~h}$ & 409.75 & 207.49 & 2.22 & 0.51 & 222.56 & 0.81 & 230.00 & 0.932 \\
\hline $96 \mathrm{~h}$ & 436.79 & 229.64 & 1.87 & 0.53 & 190.08 & 1.15 & 214.37 & 0.948 \\
\hline
\end{tabular}

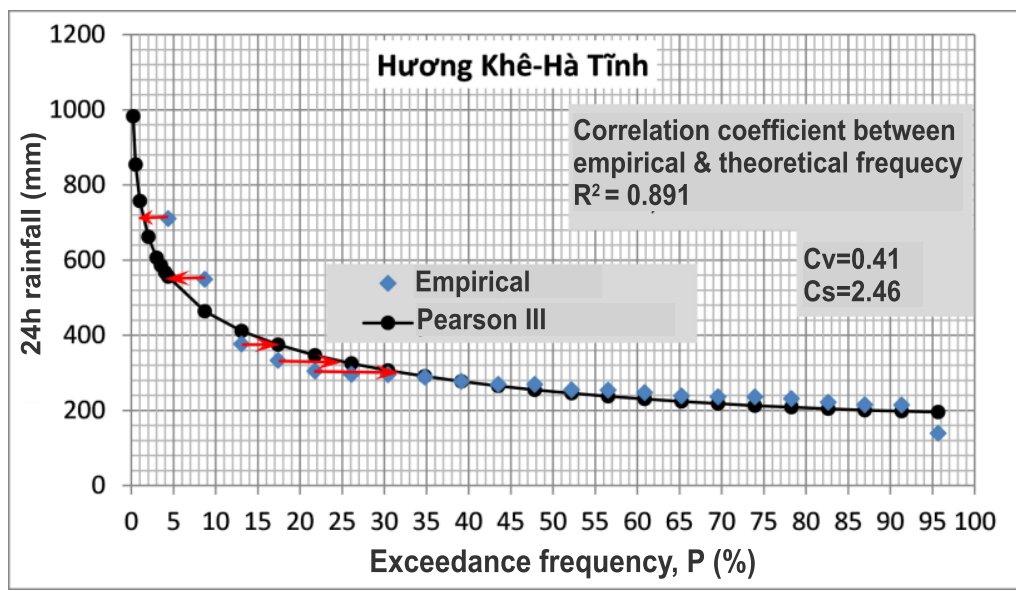

Figure 3. Empirical frequency and Pearson III distribution of continuous 24h rainfall (1990-2012). 


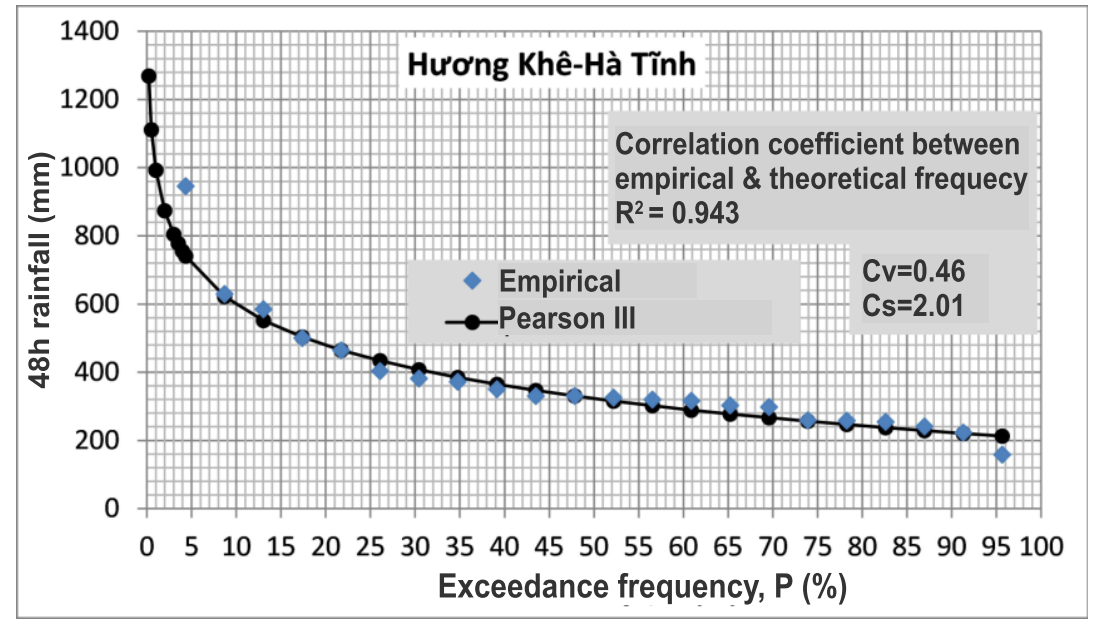

Figure 4. Empirical frequency and Pearson III distribution of continuous 48h rainfall (1990-2012).

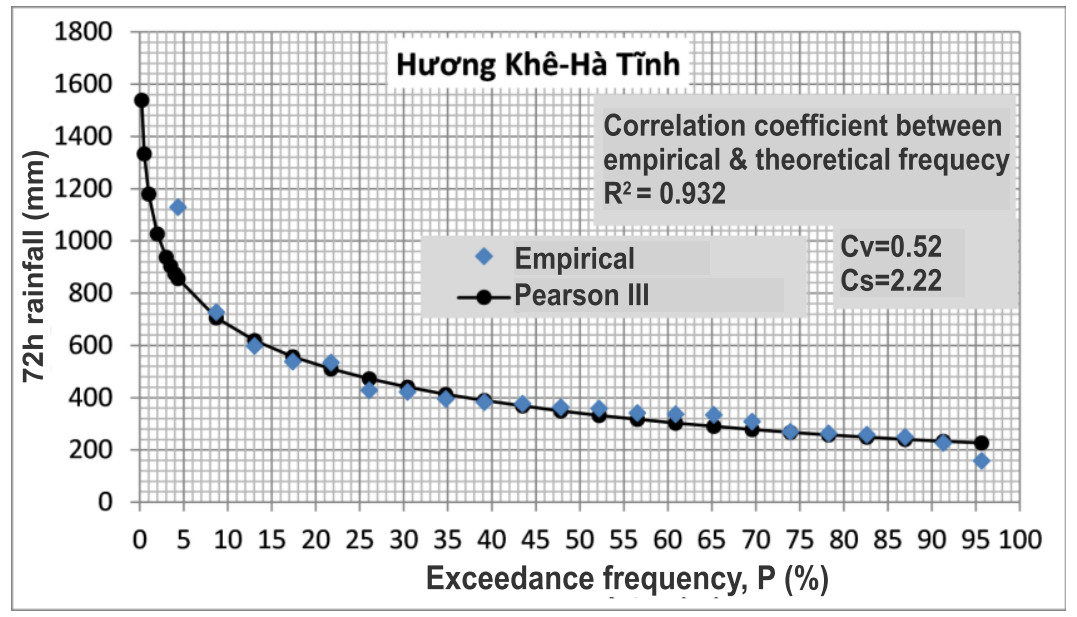

Figure 5. Empirical frequency and Pearson III distribution of continuous 72h rainfall (1990-2012).

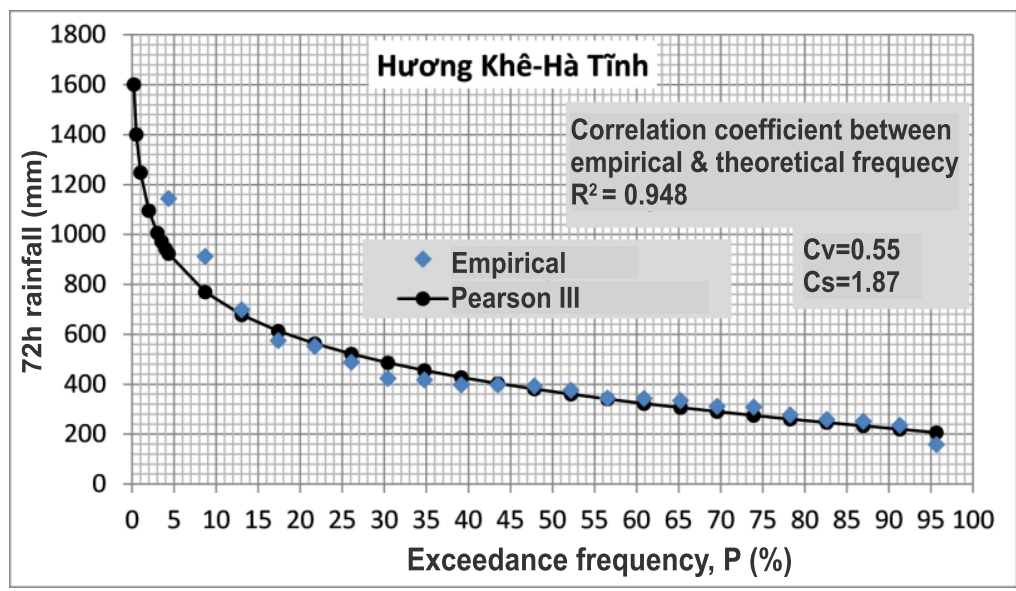

Figure 6. Empirical frequency and Pearson III distribution of continuous 96h rainfall (1990-2012). 


\section{Conclusions and discussions}

Based on rainfall duration and intensity in the period of 1990-2012, the flood-causing rainfall in Huong Khe, Ha Tinh has the following characteristics:

- Flood occurs when the continuous $24 \mathrm{~h}$ rainfall reaches $710.6 \mathrm{~mm}$ (2007) or more;

- Flood occurs when the heavy rain lasts from $24 \mathrm{~h}$ to $48 \mathrm{~h}$ with the rainfall of over $548.9 \mathrm{~mm} / 24 \mathrm{~h}$ and $630.2 \mathrm{~mm} / 48 \mathrm{~h}(2010)$;

- Flood occurs when the heavy rain lasts from $72 \mathrm{~h}$ to $96 \mathrm{~h}$ with the rainfall of over $534.5 \mathrm{~mm} / 72 \mathrm{~h}$ and $575.6 \mathrm{~mm} / 96 \mathrm{~h}$ (2002).

This is the basis for the prediction of flood risk in the region according to the rainfall trend analysis of heavy rain of under $24 \mathrm{~h}$ that can cause flood, or heavy rain of over $24 \mathrm{~h}$ that does not cause flood, but can lead to flood in the area when it continues to last over $24 \mathrm{~h}$.

Based on the determination of empirical an theoretical exceedance frequencies of Pearson III distribution of continuous 24h-96h rainfall, it is possible to draw some following remarks and discussions:

All the theoretical and empirical frequency data have very high correlation coefficient from 0.891 ( $24 \mathrm{~h}$ rainfall) to about 0.948 ( $72 \mathrm{~h}-96 \mathrm{~h}$ rainfall);

- For $24 \mathrm{~h}$ rainfall, the actual rainfall of the empirical $P$ of $13 \%$ to $26 \%$ is about $40 \mathrm{~mm}$ lower than the theoretical rainfall, while the actual rainfall of the empirical $P$ of $8.7 \%$ is about $80 \mathrm{~mm}$ higher than the theoretical value, and that of the empirical $P$ of $4.35 \%$ is about $175 \mathrm{~mm}$ higher than the theoretical value; the actual rainfall at empirical $P$ of $8.7 \%$ is corresponding to theoretical $P$ of $4.5 \%$, and actual rainfall at empirical $P$ of $4.35 \%$ is corresponding to theoretical $P$ of $\sim 1 \%$ (presented by red arrows in Figure 2). This is consistent with the actual flooding in the region when the flood in 2007 is considered the historic hundred-year flood.

- For $48 \mathrm{~h}$ and $72 \mathrm{~h}$ rainfall, the empirical and theoretical frequency data are very close to each other for the $P$ in the range of $8.7 \%$ to $30 \%$, only empirical $P$ of $4.35 \%$ is much far from theoretical one and corresponding to rainfall frequency of $\sim 1 \%$;

- For 96h rainfall, the empirical and theoretical frequency data are very close to each other for most $P$ range, only empirical $P$ of $8.7 \%$ and $4.35 \%$ are somehow far from theoretical ones and corresponding to rainfall of theoretical frequencies of $\sim 4.5 \%$ and $\sim 1 \%$, respectively.

Furthermore, in accordance with Nguyen Khanh Van et. al. (2013) [16], there is a certain relationship between the resonant influences of topo-geographic conditions in spatial heavy rainfall patterns in the Coastal Central Region of Vietnam, it would be a scientific and practical significance of a study on the different exceedance frequency distributions of extreme rainfalls over the areas along N-S direction by E-W orientation mountain ranges (the Ngang, the Hai Van and the Ca mountainous passes).

\section{References}

[1] Nguyen Khanh Van, 2009. Project report: Study on causes and occurrence mechanism of floodcausing rain and unseasonal heavy rain recommendation of solutions for disaster control and mitigation in Central Vietnam. Institute of Geography - Vietnam Academy of Science and Technology.

[2] Nguyen Khanh Van, 2012. Role of topogeographical conditions in the North Central region and the difference of heavy rain between North and South of Ngang Pass. Vietnam Journal of Earth Sciences. Vol. 34 (1), 2012, pp. 38-46.

[3] Le Van Nghinh and Hoang Thanh Tung, 2006. Solutions for flood control and mitigation in the Central region. Journal of Water Resources and Environmental Engineering. No. 14 (8/2006), pp. 44-47.

[4] Vietnam Institute of Meteorology, Hydrology and Environment, 1999. Final report of project: the establishment of map of maximum one-day rainfall for Central Coast and Central Highlands until 1999. Ministry of Natural Resources and Environment. 
[5] Le Van Nghinh, 2004. The problem of warning and prediction of beyond-design floods for medium and small reservoirs. Journal of Water Resources and Environmental Engineering. No. 7 V (11/2004), pp. 98-104.

[6] Pham Ngoc Quy, 2006. Recommendation of design flood criteria for designing emergency spillway. Journal of Water Resources and Environmental Engineering. No. 12 (3/2006), pp. 8-11.

[7] Nguyen Tuan Anh, 2014. Studying the determination of a number of rain parameters to make contributions to completing the formula of design flow of small sized drain works on road under the climatic conditions of Vietnam. Ph.D. thesis. Hanoi university of transportation.

[8] Ngo Le An, 2016. Changing trends in annual maximum daily precipitation in Central Highland regions in context of climate change. Journal of Water Resources and Environmental Engineering. No.52 (3/2016), pp. 77-84.

[9] Doan Thi Noi, 2016. Study on flooding variation and scientific basis for flood calculation for transportation in the Northeast region of Vietnam. PhD Thesis. Water Resources University.

[10] Dang Dinh Kha, Tran Ngoc Anh and Mai Thi Nga, 2015. Application of WEAP model to integrated water balance in Lam River basin.
Journal of Science: Natural Sciences and Technology. Vol. 31, No. 3S (2015), pp. 186-194.

[11] Nguyen Khanh Van, Bui Minh Tang, 2004. The characteristics of weather patterns causing heavy, serious rain and flood in Thanh Hoa, Nghe An, Ha Tinh provinces, from 1997 to 2001. Vietnam Journal of Earth Sciences. Vol. 26 (1), pp. 50-59.

[12] Geoffrey S. Dendy, 1987. A 24-hour rainfall distribution and peak rate factors for use in Southwest Florida. USA.

[13] National Centre for Hydro-Meteorological Forecasting - Ministry of Natural Resources and Environment. The hydrometeorological observation data in Ha Tinh.

[14] Ven Te Chow, David R. Maidment, Larry W. Mays, 1988. Applied Hydrology. McGraw-Hill Inc.

[15] Kritsky S. N. and Menkel M. F., 1967. Principles of estimation methods of maximum discharge. Floods and their computation. Proceedings of the Leningrad Symposium. August 1967. Vol. 1, pp. 29-40.

[16] Nguyen Khanh Van, Tong Phuc Tuan, Vuong Van $\mathrm{Vu}$, Nguyen Manh Ha, 2013. The heavy rain differences in the Coastal Central Region of Vietnam from Thanh Hoa to Khanh Hoa based on topo-geographical analyze. Vietnam Journal of Earth Sciences. Vol. 35 (4), 2013, pp. 301-309.

\title{
Nghiên cứu tần suất mưa lớn khu vực huyện Hương Khê tỉnh Hà Tĩnh
}

\author{
Nguyễn Văn Lợi ${ }^{1}$, Lê Quang Đạo ${ }^{1}$, Đông Thu Vân ${ }^{2}$, \\ Phạm Lan $\mathrm{Hoa}^{2}$, Lê Thanh Tùng ${ }^{2}$ \\ ${ }^{I}$ Trung tâm Tư vấn và Chuyển giao công nghệ Thuỷ lợ-TC TL-Bộ NNPTNT \\ ${ }^{2}$ Viện Địa chát-Viện Hàn lâm Khoa học và Công nghệ Việt Nam
}

Tóm tắt: Cường độ mưa theo thời đoạn mưa, tần suất mưa và lượng mưa liên tục $24 \mathrm{~h}$ hoặc dài hơn $(48 \mathrm{~h}, 72 \mathrm{~h}, 96 \mathrm{~h})$ là rất cần thiết cho các công tác đánh giá nguy cơ lũ lụt và thiết kế các công trình hồ đập khu vực huyện Hương Khê tỉnh Hà Tĩnh. Các kết quả phân tích đặc trưng mưa gây lũ và thực tế lũ lụt tại khu vực từ năm 1990 đến 2012 cho thấy khu vực xảy ra lũ lụt khi: a) Mưa liên tục 24h đạt tới $710,6 \mathrm{~mm}$; b) Mưa lớn kéo dài liên tục trên $24 \mathrm{~h}$ với lượng mưa đạt tới trên $548,9 \mathrm{~mm} / 24 \mathrm{~h}$ và tới $630,2 \mathrm{~mm} / 48 \mathrm{~h}$; c) Thường xảy ra lũ lụt khi mưa lớn kéo dài trên $72 \mathrm{~h}$ đến $96 \mathrm{~h}$, với lượng mưa đạt tới trên $534,5 \mathrm{~mm} / 72 \mathrm{~h}$ và tới $575,6 \mathrm{~mm} / 96 \mathrm{~h}$. Kết quả phân tích xây dựng đường tần suất $(P)$ vượt thực nghiệm và tần suất lý luận Pearson III mưa lớn liên tục 24h-96h cho kết quả: a) Tất cả các đường tần 
suất vượt lý luận và thực nghiệm có hệ số tượng quan rất chặt chẽ, thấp nhất là 0,891 (mưa liên tục 24h) và tới khoảng 0,948 (mưa liên tục $72 \mathrm{~h}-96 \mathrm{~h}$ ); b) Đối với mưa liên tục $24 \mathrm{~h}$, lượng mưa thực tế ở các $P$ thực nghiệm từ $13 \%$ đến $26 \%$ thấp hơn lượng mưa lý luận khoảng $40 \mathrm{~mm}$, trong khi đó lượng mưa thực tế ở các $P$ thực nghiệm $8,7 \%$ cao hơn lượng mưa lý luận khoảng $80 \mathrm{~mm}$, và ở $P$ thực nghiệm $4,35 \%$ cao hơn khoảng $175 \mathrm{~mm}$; lượng mưa ở $P$ thực nghiệm $8,7 \%$ tương đương với $P$ lý luận $\sim 4,5 \%$ và lượng mưa ở $P$ thực nghiệm $4,35 \%$ tương đương với $P$ lý luận $~ 1 \%$; c) Đối với mưa liên tục $48 \mathrm{~h}$ và $72 \mathrm{~h}$, các đường tần suất lý luận và thực tiễn rất gần nhau ở dải giá trị $8,7 \%$ đến $30 \%$, chỉ riêng $P$ thực nghiệm $4,35 \%$ nằm lệch tương đối lớn và tương ứng với lượng mưa tần suất lý luận $~ 1 \% ; \mathrm{d}$ ) Đối với mưa $96 \mathrm{~h}$, các đường tần suất lý luận và thực tiễn cũng rất gần nhau ở mọi dải giá trị, chỉ riêng $P$ thực nghiệm $8,7 \%$ và $4,35 \%$ nằm lệch tương đối lớn, và tương ứng với lượng mưa tần suất lý luận $4,5 \%$ và $~ 1 \%$.

Tù khóa: Cực trị, tần suất, Pearson, Gamma, Kritsky-Menken, độ lệch chuẩn, hệ số thiên lệch. 